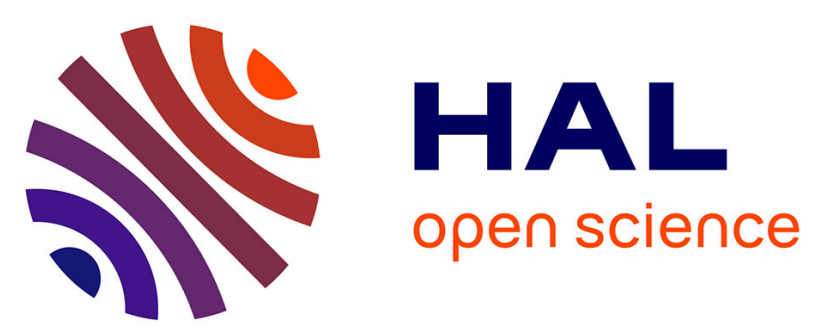

\title{
Modeling the spread of the pine processionary moth in relation with climate change and human activities
}

Christelle Robinet, Jérôme Rousselet, Mathieu Laparie, Alain Roques

\section{To cite this version:}

Christelle Robinet, Jérôme Rousselet, Mathieu Laparie, Alain Roques. Modeling the spread of the pine processionary moth in relation with climate change and human activities. ICE 2016; XXV International Congress of Entomology, Sep 2016, Orlando, United States. 10.1603/ICE.2016.93400 . hal-02798958

\section{HAL Id: hal-02798958 \\ https://hal.inrae.fr/hal-02798958}

Submitted on 5 Jun 2020

HAL is a multi-disciplinary open access archive for the deposit and dissemination of scientific research documents, whether they are published or not. The documents may come from teaching and research institutions in France or abroad, or from public or private research centers.
L'archive ouverte pluridisciplinaire HAL, est destinée au dépôt et à la diffusion de documents scientifiques de niveau recherche, publiés ou non, émanant des établissements d'enseignement et de recherche français ou étrangers, des laboratoires publics ou privés. 


\section{Thursday, September 29, 2016}

01:45 PM - 02:00 PM

Introduction: The pine processionary moth, Thaumetopoea pityocampa, occurs in large parts of southern Europe, Asia Minor and North Africa and is currently extending its range. This insect species causes phytosanitary problems especially in pine forests, but it also affects human health because late instars larvae are urticating and can also occur in urban areas on ornamental pine trees. In France, valuable historical datasets on the species occurrence and population dynamics are available since the 1970s, providing a solid baseline to compare with ongoing changes.

Methods:The northern edge of the species distribution was surveyed at large scales: at country scale in France over an 8-km grid (at 5-year intervals: 2006, 2011, and 2016) and at continental scale across its range over a 16-km grid (in 2012). We developed a spread model accounting for: (1) larval survival in winter and observed climate warming, and (2) human-mediated dispersal. This model was applied in France to test various hypotheses and make predictions under IPCC climate change scenarios.

Results/Conclusion: The spread model shows that the pine processionary moth started to extend its distribution in France in the early 1990s with higher winter minimum temperature and human-mediated dispersal has accelerated the spread. The species may continue to spread in the future despite some uncertainties. Until now changes in phenology and prolonged diapause have been ignored whereas they could potentially alter the species distribution. The challenge is now to consider stage-specific thermal thresholds of subsequent life stages and inter-populational heterogeneity in phenology.

doi: 10.1603/ICE.2016.93400

\section{Authors}

Christelle Robinet

INRA

Jérôme Rousselet

INRA

Mathieu Laparie

INRA

\section{Alain Roques}

INRA

\section{View Related Events}

Symposium: Approaches for Modeling Insect Pest Potential Distribution and Spread

Program: Symposium

Day: Thursday, September 29, 2016 